\title{
Pierre Trudeau was Canada's Greenest Prime Minister
}

\author{
John SW Gillis, PhD \\ St. Thomas University \\ jgillis@stu.ca
}

\section{Introduction}

In Feb 1984, Dan Rather sent a TV crew from the CBS Evening News to interview me about the American presidential election.

The next day I flew to Hawaii to visit one of the world's most brilliant psychologists, Psychology's Secret Genius. We discussed many topics but focused on personalities of politicians.

As a result of these conversations, I began to study the personalities of Canadian Prime Ministers:

John A. MacDonald, Charles Tupper, Wilfred Laurier, Mackenzie King, John Diefenbaker, Lester Pearson,

Pierre Trudeau, Brian Mulroney and Jean Chrétien.

Here I explain why I believe Pierre Trudeau was Canada's Greenest Prime Minister.

\section{Procedure and Results}

Nine independent experts answered the Sixteen Personality Factors Test (16PF) "as if" they were one of the Prime Ministers. 
The results are listed below:

\begin{tabular}{|c|c|c|c|c|c|c|c|c|c|c|c|c|c|}
\hline \multirow[t]{2}{*}{$\mathbf{a}$} & & $E$ & & $\mathbf{g}$ & & I & & $\mathbf{M}$ & $\mathbf{N}$ & 0 & Q1 & Q2 & \\
\hline & & $\mathrm{E}$ & $\mathrm{F}$ & & $\mathrm{H}$ & $\mathrm{i}$ & $\mathrm{L}$ & & & 0 & Q1 & q2 & Q3 \\
\hline$A$ & & $E$ & $F$ & $\mathrm{~g}$ & $\mathrm{H}$ & I & & $\mathrm{M}$ & & & & q2 & \\
\hline \multirow[t]{2}{*}{$A$} & $C$ & $E$ & & & $\mathrm{H}$ & & $\mathrm{L}$ & & & & & q2 & Q3 \\
\hline & C & $E$ & & & $\mathrm{H}$ & & & & & 0 & Q1 & & Q3 \\
\hline$A$ & $c$ & $\mathrm{E}$ & & & $\mathrm{H}$ & & & $M$ & & 0 & & & \\
\hline \multirow[t]{3}{*}{$A$} & C & $E$ & $F$ & $\mathrm{G}$ & & & $\mathrm{L}$ & & $\mathrm{N}$ & & Q1 & & Q3 \\
\hline & C & $E$ & & $\mathrm{G}$ & $\mathrm{H}$ & & & & & & $q 1$ & & \\
\hline & & $E$ & $f$ & & & & $\mathrm{~L}$ & & & & & & Q3 \\
\hline
\end{tabular}

Rows contain scores of Prime Ministers, listed in random order.

Pierre Trudeau is in bold type on the first line.

The late Honourable Andy Scott MP completed the 16PF based on his knowledge of and personal experience with Trudeau.

Each column contains letters representing scores on 15 of the 16PF personality factors.

An UPPER CASE letter indicates an above average score.

A lower case letter signifies a below average score.

A blank space represents an average score.

Trudeau scored above average on Factors E, I, M, N, Q1, Q2 and Q4.

He scored below average on factors $A, G$ and $O$.

He scored average on factors C, F, H, L and Q3. 


\title{
Discussion
}

The personality profiles of the Prime Ministers show that Pierre Trudeau differed from the others in a variety of important ways. Only one other PM scored above average on Factor I, and the raw data indicates Pierre was much higher. Factor I is defined as a general dimension of Sensitivity.

Reading the Prologue of an autobiography Common Ground by his son, Justin, gives both a brilliant depiction of what a high on I person tends to be like, and illustrates tremendous insight into Pierre's genuinely passionate love of nature.

Here is a brief excerpt:

"It was when we paddled or hiked together back then that we felt closest as a family. The city was where the stress of work and politics would sometimes beat his family down. The outdoors was where we relaxed by getting in touch with who we were and not what others wanted us to be. Together, we learned to face down obstacles and overcome our fears and we developed an endless appreciation for our country and its great natural beauty."

No other Prime Minister spent more time exploring the wilderness of Canada. Were he alive today, clearly Pierre Trudeau would be leading efforts to deal with the Climate Crisis.

\section{Acknowledgements}

Thanks to the following people for valuable assistance in some aspect of this investigation.

\author{
Brad Cross, PhD \\ Juergen Doerr, PhD \\ Michael Higgins, PhD \\ Russ King, MD \\ Noël Kinsella, PC
}


Rick Myers, PhD

Dan O'Brien, $\mathrm{PhD}$

David Adams Richards, CM, ONB

Andy Scott, PC

Bill Spray, PhD

Of course, none of the above share any responsibility for the views expressed herein. 